\title{
Mental Health Research in Primary Care: Mandates from a Community Advisory Board
}

\author{
Roberto Chené, $M A^{1}$ \\ Lorenzo García, BUS ${ }^{2}$ \\ Margie Goldstrom, BA, RN ${ }^{3}$ \\ Mandy Pino, MS ${ }^{4}$ \\ Delfy Peña Roach, $B A^{5}$ \\ Wendy Thunderchief, MA, $L P C^{6}$ \\ Howard Waitzkin, $M D, P b D^{7}$ \\ ${ }^{1}$ The Southwest Center for Intercultural \\ Leadership, Albuquerque, NM \\ ${ }^{2}$ The New Mexico Public Health Association \\ and New Mexico Department of Health, \\ Albuquerque, NM \\ ${ }^{3}$ The Albuquerque Chapter of the National \\ Alliance for the Mentally Ill, \\ Albuquerque, NM \\ ${ }^{4}$ Health Action New Mexico, \\ Albuquerque, NM \\ ${ }^{5}$ Parents for Behaviorally Different Children, \\ Albuquerque, NM \\ ${ }^{6}$ Thunderchief Cultural Consulting and \\ Mental Health Advocacy, Albuquerque, NM \\ ${ }^{7}$ Department of Family and Community \\ Medicine, University of New Mexico, \\ Albuquerque, NM
}

Conflicts of interest: none reported

\section{CORRESPONDING AUTHOR}

Howard Waitzkin, MD, PhD

Department of Family

and Community Medicine

1 University of New Mexico,

MSC09 5060

2400 Tucker Avenue NE

Albuquerque, NM 87131-0001

waitzkin@unm.edu.

\begin{abstract}
PURPOSE We wanted to obtain the viewpoints of a community advisory board in training junior minority faculty members and graduate students for communitybased participatory research (CBPR) on mental health in primary care.
\end{abstract}

METHODS During training institutes, members of a community advisory board presented plenary sessions on research collaboration with communities. The program director edited the transcribed recordings of the presentations for style but not for content. Advisory board members collaborated in revising the transcripts and summarizing themes.

RESULTS Board members expressed several key themes. Research must take into account traditional healing practices and prior exploitative research. Historical trauma impedes collaborations, which require conflict resolution and departure from traditional definitions of normalcy. Researchers should include communities in formulating research agendas and should take findings back to the communities for critical appraisal and practical applications. Collaborations should address policy issues including interpreter services, Medicaid managed care, and parity in insurance coverage for physical and mental health problems.

CONCLUSIONS Community advisory board members present key concerns that otherwise would not enter into the researchers' training curriculum. Such an advisory board can make important contributions to programs that seek to improve CBPR in mental health and primary care.

Ann Fam Med 2005:3:70-72. DOI: 10.1370/afm.260.

\section{INTRODUCTION}

$\mathrm{P}$ articipatory research, according to a recent definition, involves systematic enquiry in collaboration with those affected by the issue being studied for the purpose of education and taking action or effecting social change. ${ }^{1}$ Several projects involving university teams and community organizations have encouraged community-based participatory research (CBPR). ${ }^{2.7}$ Recognition that complex health and social problems are not suited to traditional outside expert approaches to research has led to calls for more collaborative CBPR approaches. ${ }^{1,8-10}$ New strategies challenge the traditional dichotomy between researchers and subjects of research ${ }^{11-13}$ and emphasize minority or underserved communities. ${ }^{14}$ Such strategies rarely have entered mental health services research in primary care.

We have addressed the question: How can junior investigators, mainly from minority ethnic or racial backgrounds, gain information on CBPR at the interface of mental health and primary care from the standpoint of community participants?

\section{METHODS}

\section{Context}

Since 1998, the University of New Mexico (UNM) has initiated 2 programs to improve research training for junior minority faculty members 
and graduate students. Four minority faculty members (Drs Bonnie Duran, Rodrigo Escalona, Irene Ortíz, and Ervin Lewis) initiated the programs, which focus on poor and underserved communities, and sought help from 2 senior faculty members (Drs Howard Waitzkin and Joel Yager). With funding from the National Institute of Mental Health, both programs try to address a nationally recognized gap in training opportunities. ${ }^{15-18}$ The first program, the Minority Research Infrastructure Support Program (M-RISP), aims to enhance mentoring for junior faculty based at UNM. The M-RISP has provided individualized mentoring, biostatistical consultation, data management services, and partial salary support. A second program, the New Mexico Mentorship and Education Program (MEP), seeks to expand mentorship opportunities to include junior minority faculty members based at institutions throughout the Southwest region. In the MEP, national leaders in mental health services research oriented to minority populations serve as mentors. The MEP also sponsors a 1 -week annual institute in which mentors and mentees share their work and learn about advances in research methodology and findings.

\section{The Community Advisory Board}

Board members include leaders of community organizations that focus on issues in mental health and primary care: Roberto Chené is director of the Southwest Center for Intercultural Leadership in Albuquerque. Lorenzo García, president of the New Mexico Public Health Association, has worked as a health promotion manager with the New Mexico Department of Health. Margie Goldstrom, a retired nurse, serves on the board of the Albuquerque chapter of the National Alliance for the Mentally Ill. Mandy Pino is a founding member of Health Action New Mexico, a statewide advocacy organization. Delfy Peña Roach is executive director of Parents for Behaviorally Different Children, a statewide advocacy organization in New Mexico. Wendy Thunderchief works as a cultural consultant and mental health advocate, especially for American Indian women and children.

\section{Analysis and Preparation of Findings}

At the MEP annual institutes, advisory board members have coordinated plenary sessions, where they have presented their experiences and views about research collaboration with communities. During 2002, transcriptionists prepared a verbatim transcript of the oral presentations. Howard Waitzkin edited the transcript for style but not for content. He then coded and categorized the transcript for key themes according to established analytic techniques for qualitative research. ${ }^{19,20}$ Next, he presented the edited transcript and summary of the themes to the advisory board members. After reviewing the transcript and themes, each board member suggested revisions concerning his or her own contribution. The final article incorporated the suggested revisions, which all board members reviewed and approved before publication.

\section{RESULTS}

Advisory board members presented several themes concerning CBPR at the interface of mental health and primary care. The Appendix, ${ }_{1}^{21-24}$ which contains the revised transcript, provides the full presentations of these themes. (The Appendix is available as online-only supplemental data and can be found at http://www. annfammed.org/cgi/content/full/3/1/70/DC1.)

- Community-based advocacy organizations can benefit from researchers' input.

- Those conducting research must take into account cultural differences, traditional ceremonies and healing practices, and a history of exploitative research.

- Historical trauma and ongoing conflict impede collaborations between researchers and communities unless researchers develop skills in working with discomfort and conflict resolution.

- Such collaborations require a departure from conformity, a questioning approach about definitions of normalcy, and acknowledgment of social and structural issues in mental health and primary care.

- Researchers should include communities in formulating research agendas, questions, and priorities and should take their findings back to the communities for critical appraisal and practical applications.

- These collaborations should address policy issues, such as the need for interpreter services, the impact of Medicaid managed care on mental health services, and parity in insurance coverage for physical and mental health problems.

\section{DISCUSSION}

In CBPR few models exist for community participation in educating researchers. Our community advisory board members have provided a unique form of mentoring in which community residents and activists participate jointly with nationally prominent investigators in educating researchers about CBPR in mental health and primary care.

We encourage recognition that community advisors can become eloquent and enlightening mentors. They can advise about priorities and about suitable processes for nonexploitative research. Mentoring by community advisors can become as important as training in research concepts and methods. 
To read or post commentaries in response to this article, see it online at http://www.annfammed.org/cgi/content/full/3/1/70.

Key words: Mental health services; primary health care; health care delivery; health services research; New Mexico; health policy; consumer participation; ethnic groups; minority groups

Submitted December 28, 2003; submitted, revised, April 14, 2004; accepted April 29, 2004.

Funding support: This work was supported in part by grants (1R24 MH58404 and 1R25 MH60288) from the National Institute of Mental Health.

Acknowledgments: Marilyn Diener and Julia Taylor provided assistance in the preparation of the manuscript. Tassy Parker and Gloria López helped organize the training institute. Joel Yager contributed as co-program director and through his helpful comments on the manuscript.

\section{References}

1. Green LW, George MA, Daniel M, et al. Study of Participatory Research in Health Promotion: Review and Recommendations for the Development of Participatory Research in Health Promotion in Canada. Vancouver, British Columbia: Royal Society of Canada; 1995.

2. Davis S, Reid R. Practicing participatory research in American Indian communities. Am J Clin Nutr. 1999;69(4 Suppl):755S-759S.

3. Wallerstein N. A participatory evaluation model for healthier communities: developing indicators for New Mexico. Public Health Rep. 2000; 115:199-204.

4. Wallerstein N. Power between evaluator and community: research relationships within New Mexico's healthier communities. Soc Sci Med. 1999;49:39-53.

5. Minkler M. Using participatory action research to build healthy communities. Public Health Rep. 2000;115:191-197.

6. Israel BA, Schulz AJ, Parker EA, Becker AB. Review of community-based research: assessing partnership approaches to improve public health. Annu Rev Public Health. 1998;19:173-202.

7. Helitzer D, Willging C. Navajo Nation evaluation [Funded grant application]. National Institute of Occupational Safety and Health; 2001.

8. Minkler M, Wallerstein N, eds. Community Based Participatory Research for Health. San Francisco, Calif: Jossey Bass; 2003.

9. Israel BA, Shultz AJ, Parker EA, Becker AB, Allen AJ, Guzman RJ. Critical issues in developing and following community based participatory research principles. In: Minkler M, Wallerstein N, eds. Community Based Participatory Research for Health. San Francisco, Calif: Jossey Bass, 2003:53-76.
10. Crabtree SA, Wong CM, Masud F. Community participatory approaches to dengue prevention in Sarawak, Malaysia. Hum Organ. 2001;60:281-287.

11. Judd J, Frankish CJ, Moulton G. Setting standards in the evaluation of community-based health promotion programmes: a unifying approach. Health Promot Int. 2001;16:367-380.

12. Campbell JR. Participatory rural appraisal as qualitative research: distinguishing methodological issues from participatory claims. Hum Organ. 2001;60:380-389.

13. Waitzkin H. At the Front Lines of Medicine: How the Health Care System Alienates Doctors and Mistreats Patients... and What We Can Do About it. Lanham, MD: Rowman and Littlefield; 2001.

14. Macaulay AC, Gibson N, Freeman W, et al, for the North American Primary Care Research Group. Participatory research maximises community and lay involvement. BMJ. 1999;319:774-778.

15. Ruíz P: Issues in the psychiatric care of Hispanics. Psych Serv. 1997;48:539-540.

16. Meyer RE, McLaughlin CH: Between Mind, Brain, and Managed Care: the Now and Future World of Academic Psychiatry. Washington, DC: American Psychiatric Press; 1997.

17. Thomas DA. The truth about mentoring minorities: race matters. Harv Bus Rev. 2001;39:7-17,98-107,168.

18. Pope-Davis DB, Liu WM, Toporek RL, Brittan-Powell CS: What's missing from multicultural competency research: review, introspection, and recommendations. Cultur Divers Ethnic Minor Psychol. $2001 ; 7: 121-138$.

19. Strauss A, Corbin J. Basics of qualitative research: grounded theory procedures and techniques. Newbury Park, Calif: Sage Publications 1998.

20. Crabtree B, Miller WL, eds. Doing Qualitative Research. 2nd ed. Thousand Oaks, Calif: Sage Publications; 1999.

21. Waitzkin $\mathrm{H}$. Is our work dangerous? Should it be? (presentation on receipt of Leo G. Reeder Career Recognition Award, American Sociological Association, August 1997). J Health Soc Behav. 1998;39:7-17.

22. Waitzkin H, Williams RL, Bock JA, McCloskey J, Willging C, Wagner W. Safety-net institutions buffer the impact of Medicaid managed care: a multi-method assessment in a rural state. Am J Public Health. 2002;92:598-610.

23. Schillaci MA, Waitzkin H, López CM, Boehm DA, López LA, Mahoney SF. Immunization coverage and Medicaid managed care in New Mexico: a multi-method assessment. Ann Fam Med. 2004;2:13-21.

24. Willging C, Semansky R, Waitzkin H. Medicaid managed care waivers for mental health services. Psych Serv. 2003;54:289-291. 